\title{
Spatial and temporal analysis of the human immunodeficiency virus in an area of social vulnerability in Northeast Brazil
}

\author{
Géssyca Cavalcante de Melo, ${ }^{1,2}$ Emilia Carolle Azevedo de Oliveira, ${ }^{3}$ Iane Brito Leal, ${ }^{2}$ \\ Carolina Piedade Morais de Freitas Soares Silva, ${ }^{3}$ Roberta Andrade Beltrão, ${ }^{3}$ \\ Allan Dantas dos Santos, ${ }^{4}$ Renata Karina Reis, ${ }^{5}$ Marco Antônio Prado Nunes, ${ }^{2}$ \\ Karina Conceição Gomes Machado de Araújo ${ }^{2}$
}

${ }^{1}$ State University of Health Sciences of Alagoas, Alagoas; ${ }^{2}$ Postgraduate Program in Health Science, Federal University of Sergipe; ${ }^{3}$ Instituto Aggeu Magalhães, Fundação Oswaldo Cruz, Pernambuco; ${ }^{4}$ Postgraduate in Nursing, Federal University of Sergipe, Sergipe; ${ }^{5}$ University of São Paulo, Brazil

\begin{abstract}
Human Immunodeficiency Virus (HIV) infection still represents an important public health problem, because it involves clinical, epidemiological, social, economic and political issues. We analyzed the temporal and spatial pattern of the HIV incidence in an area of social inequality in northeast Brazil and its association with socioeconomic indicators. An ecological study was carried out with a focus on all HIV cases reported in Alagoas State, Northeast Brazil from 2007 to 2016 using its 102 municipalities as the units of our analysis. Data from the Brazilian information systems were used. Georeferenced data were analyzed using TerraView 4.2.2 software, QGis 2.18.2 and GeoDa 1.14.0. Time trend analyses were performed by the Joinpoint Regression software and the spatial analyses included the empirical Bayesian model and Moran autocorrelation. Spatial regression was used to determine the influence of space on HIV incidence rate and socioeconomic inequalities. There was an increasing trend of HIV rates, especially in the municipalities of the interior. Significant spatial correlations were observed with the formation of clusters with emphasis on the coast of the state and in tourist regions.
\end{abstract}

Correspondence: Karina Conceição Gomes Machado de Araújo, Marechal Rondon Avenue, São Cristóvão-SE, Zip code 49100-000, Brazil.

E-mail: karinaconceicaoaraujo@gmail.com

Key words: HIV; social vulnerability; spatiotemporal analysis; epidemiology, Brazil.

Conflict of interests: The authors declare no potential conflict of interests.

Received for publication: 7 February 2020.

Accepted for publication: 30 September 2020.

CCopyright: the Author(s), 2020

Licensee PAGEPress, Italy

Geospatial Health 2020; 15:863

doi:10.4081/gh.2020.863

This article is distributed under the terms of the Creative Commons Attribution Noncommercial License (CC BY-NC 4.0) which permits any noncommercial use, distribution, and reproduction in any medium, provided the original author(s) and source are credited.
Spatial regression explained $46 \%$ of the dependent variable. The HIV incidence rate was positively influenced by rate of primary health care units $(\mathrm{P}=0.00)$, and negatively by Gini index $(\mathrm{P}=0.00)$ and proportion of heads of household without or low education $(\mathrm{P}=0.02)$. We conclude that the relationship found between indicators of better socioeconomic conditions and HIV infection suggests unequal access to the diagnosis of infection. Prevention and control strategies can be established according to each epidemiological reality.

\section{Introduction}

Human Immunodeficiency Virus (HIV) infection still represents an important public health problem, because it involves clinical, epidemiological, social, economic and political issues. Currently, the number of people living with HIV worldwide is estimated at 37.9 million, with Latin America considered the third most affected region (UNAIDS, 2019). here, Brazil has the highest number of HIV cases (UNAIDS, 2019), despite being one of the countries that stand out in the infection treatment scenario due to the local production of drugs, free antiretroviral treatment protocols and universal access (Galvão, 2002a; Galvão, 2002b). From 2007 to June 2019, 300,496 cases of HIV were registered in the country by the Ministry of Health $(\mathrm{MoH})$, and the current incidence rate of the Acquired Immunodeficiency Syndrome (AIDS) is 18.3 cases per 100,000 inhabitants $(\mathrm{MoH}, 2018)$.

There is a tendency towards a reduction in the rate of HIV detection observed in general in the country in the last 10 years. However, it is still discreet and some places, especially the Northeast, have shown a substantial increase of cases detected in the same period, which suggests the existence of concentrated epidemics (Grangeiro et al., 2015; Sousa et al., 2016; MoH, 2018). This heterogeneity can lead to the hypothesis of a relationship between the social determination of the epidemic and geographical context. Studies from different parts of the world have reported the existence of regional sub-epidemics and have shown associations between the spatial grouping of HIV incidence and mortality cases in areas with diverse individual, socioeconomic population and migration specificities (Zulu et al., 2014; Xing et al., 2014; Wand et al., 2015; Barankanira et al., 2016; Qian et al., 2014; Wabiri et al., 2016; Bose, 2017; Zhang et al., 2015; Momenyan et al., 2018).

The investigation of relationships between illness and geo- 
graphic space over time is important to elucidate the extent and severity of the infection and its impact on public health. This makes it possible to identify specific demands, priority locations and more effective and equitable control interventions. More specifically, this analysis can result in planning with the objective of early diagnosis in individuals with unknown serology enabling access to treatment, contributing to the non-development of the syndrome and consequently breaking the cycle of transmissibility. These plans are important, especially given the Fast-Track strategy (90-90-90) proposed by the Joint United Nations Programme on HIV/AIDS (UNAIDS, 2019) to end the HIV epidemic by 2030. This strategy proposes that, by $2020,90 \%$ of all people living with HIV must be diagnosed and know they carry the virus; that $90 \%$ of those diagnosed receive treatment continuously; and that, of those who receive treatment, at least $90 \%$ reach an undetectable viral load. In this study, we analysed the temporal and spatial patterns of the HIV incidence rates in an area of social inequality in northeastern Brazil and its association with socioeconomic indicators from 2007 to 2016 .

\section{Materials and methods}

\section{Design and study}

This was an ecological study with temporal and spatial components. The spatial units of analysis were the 102 municipalities in the state of Alagoas, located in north-eastern Brazil. According to the Brazilian Institute of Geography and Statistics (Instituto Brasileiro de Geografia e Estatística, IBGE), Alagoas has a population of $3,375,823$ inhabitants in an area of $278,185 \mathrm{~km}^{2}$ and has the lowest Human Development Index (HDI) in the country (IBGE, 2010). In addition, the state has the highest income inequality in the country, with a Gini index of 0.711 (IBGE, 2019).

\section{Sample, data sources and measures}

The study included all cases of HIV in individuals aged 13 years or older diagnosed during the period from 1 January 2007 to 31 December 2016. The collection of secondary data was performed based on the records of the Information System for Notifiable Diseases of the State Health Department (Sistema Nacional de Agravos de Notificação, SINAN). The case definition was considered from the International Classification of Diseases 10th revision (ICD-10: B20-B24). The rates of incidence of HIV per 100,000 inhabitants were calculated considering the number of cases in each area for every 5 years analysed (2007-2011 and 2012-2016) and for the decade (2007-2016). This frequency was divided by the population at risk based on the census estimates for the municipalities (IBGE, 2010).

As independent variables of the study, socioeconomic indicators extracted from the last national census were used and made available by IBGE (2010) and by the Institute of Applied Economic Research (Instituto de Pesquisa Econômica Aplicada; IPEA, 2015). These indicators reflect the context of social vulnerability, because they involve the contexts of human capital, health, life expectancy, economics and education expressed by the Social Vulnerability Index (SVI); the illiteracy rate; the unemployment rate; the Municipal Human Development Index (MHDI); average household income per capita; the Gini index; the proportion of heads of household without or with low education; and rate of pri- mary health care units calculated for 18,000 inhabitants, as recommended by the Brazilian health system.

\section{Data analysis}

Trends in the number of new HIV cases per year were analyzed using a model based on the assumption of a minimum number of points (Joinpoint) to describe whether they were stable, increasing or decreasing over the period of time studied and the moment when the trend had changed. The Annual Percentage Change (APC) was calculated and a 95\% confidence interval was adopted. The analysis was performed using Joinpoint Regression software (Statistical Methodology and Applications Branch, Surveillance Research Program of the National Cancer Institute, USA, version 4.7.0.0, National Cancer Institute, USA).

For the construction of spatial analysis maps, we used the cartographic base of the State of Alagoas, which is available in an electronic database of the IBGE. The georeferenced data were analysed using TerraView (National Institute for Space Research, (Instituto Nacional de Pesquisas Espaciais, INPE), SP, BR 4.2.2), Open Source Geospatial Foundation (QGIS) of OSGeo, CHI, USA, Version 2.18.2) and GeoDa (Spatial Analysis Laboratory, University of Illinois, Urbana Champaign, USA, version 1.14.0).

The maps were compiled from the average incidence rates of HIV infection recorded in two periods by municipality (2007-2011 and 2012-2016). Incidence rates were smoothed by the local empirical Bayesian method to correct random fluctuations in populations or small occurrence numbers by means of a re-estimate that considers autocorrelation between rates in neighbouring areas. For this, a weighted average was obtained between the measured value and the average neighbourhood rate, with weights inversely proportional to the population of each area (Almeida, 2012).

To estimate the variability of the space in the data analysis, a proximity matrix was built, in which the adjacent municipalities received the value 1 and those that did not have adjacent border geometries were categorized with the value 0 . The univariate Global Moran's statistic was used to identify spatial autocorrelations using values ranging from -1 to 1 , which indicate clusters of areas with similar risks for the outcome of interest. The positive indices point to the existence of spatial autocorrelation between neighbouring municipalities; negative values indicate no similarity between them; and indices close to zero mean no spatial correlation. Moran's map was used to indicate critical and transitional areas that were statistically significant, signalling the categories of the clusters and their relations with neighbours (Almeida, 2012).

We also used a spatial regression model to verify the spatial dependence of the incidence rate of HIV and socioeconomic indicators on a single parameter. First, we used Ordinary Least Squares (OLS) regression to determine spatial dependence, and then examined whether the spatial error model or the spatial lag model would be better. The residuals of the multiple linear regression model were analysed using Moran's Global index $(I)$ to verify if there was spatial autocorrelation. In addition, the method of selecting stepwise variables with stopping criteria was used by the Akaike Information Criterion (AIC) (Anselin, 2005).

The result showed that the Spatial Autoregressive (SAR) linear regression model was the most appropriate for our data. The quality of the fit of the SAR model was verified by observing the normal distribution of the residues, their values adjusted around the zero mean and the verification of the absence of autocorrelation of the residues using Moran's I (Anselin, 2005). 


\section{Results}

From 2007 to 2016, 5,454 HIV cases were reported in the study area. There was an increasing and statistically significant linear trend in the diagnosis of infection (APC 2007-2013 = 8.0; P $\leq$ 0.05 ) with a greater increase after 2013 (APC 2013-2016 $=29.03$; $\mathrm{P} \leq 0.05$ ) (Figure 1). In the second period (2012-2016), 3,556 cases were recorded. This increase occurred more significantly among municipalities in the interior of Alagoas, which presented an increase of $155 \%(n=1,582)$ in the number of registered cases compared to the first period studied $(n=656)$. In the capital of Maceió, there was an increase of $59 \%(n=1,974)$ over the first 5 years analysed $(n=1,241)$.

The incidence rate of HIV infection during the decade studied was 17.5 cases per 100,000 inhabitants (minimum 0 and maximum 36.6). Seven municipalities located in the eastern region (Matriz de Camaragibe, Maceió, Monteirópolis, Murici, Junqueiro, Marechal Deodoro and Pilar) were identified with critical detection coefficients higher than the state average, which ranged from 17.5 to 38.3 cases per 100,000 inhabitants. The municipality of Matriz de Camaragibe had the highest detection rate, despite having a population 32 times smaller than the capital Maceió.

Figure 2B illustrates the spatial distribution of the average incidence rate for the two periods, in which a growing spread of the epidemic over time is notable, with the appearance of clusters in the municipalities of Arapiraca, Junqueiro, Pilar, Marechal Deodoro, Maceió, Paripueira, Murici, Matriz de Camaragibe, Porto Calvo and Maragogi. The correction of the incidence rate by the local empirical Bayesian estimate analysis (Figure 2C and D) smoothed the rates and showed that there was variability in the transmission of the infection, with a migration pattern from the

eastern to the interior (Porto Calvo, Japaratinga, Porto de Pedras, Matriz de Camaragibe, Barra de Santo Antônio, Paripueira, Flexeiras, Messias, Maceió, Rio Largo, Coqueiro Seco, Santa Luzia do Norte, Satuba, Marechal Deodoro, Junqueiro and Arapiraca). In comparison, it is noted that, with the raw estimates (not smoothed), some municipalities have different incidences from their neighbours. In the first maps, (Figure 2A and 2B) is difficult to visualize a gradient trend large-scale incidence due to random fluctuations caused by reduced population effects. Moran's spatial analysis showed a global index value of $0.45(\mathrm{P}=0.01)$ in the first period of 2007-2011 and $0.36(\mathrm{P}=0.01)$ in the second

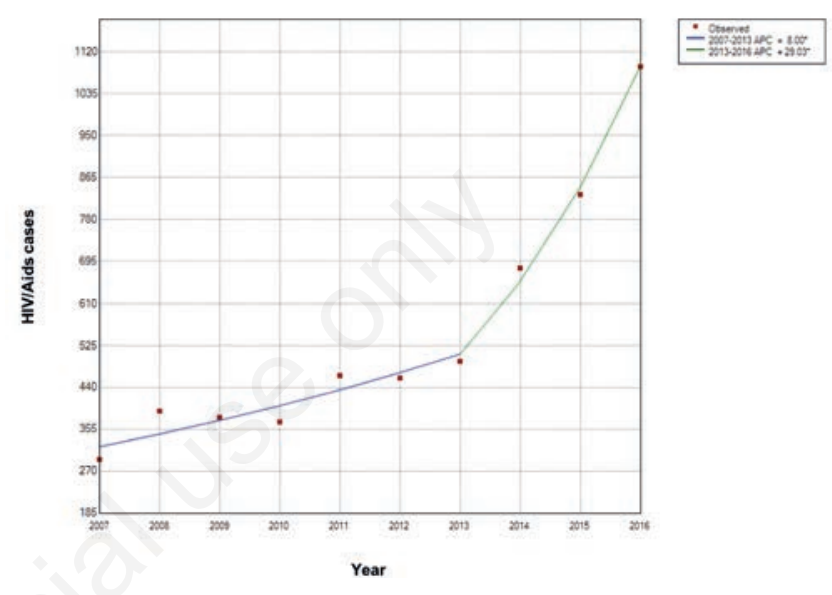

Figure 1. Temporal trend of HIV cases, Alagoas, Brazil 20072016.

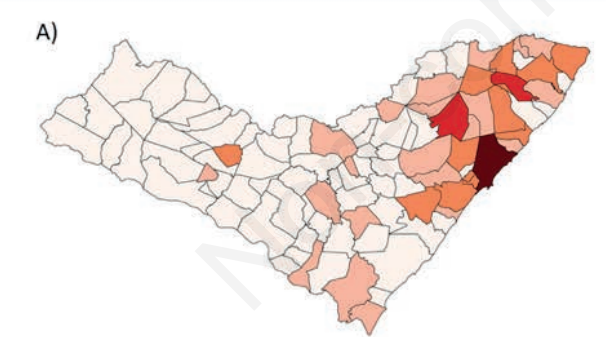

C)
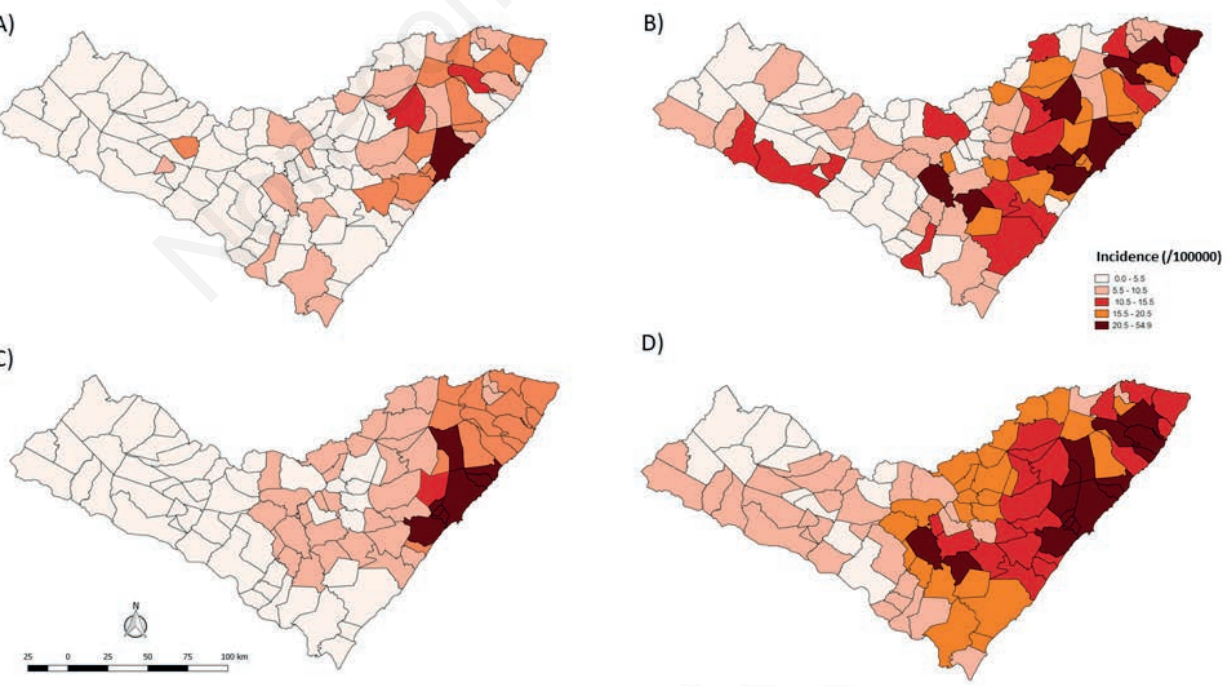

D)

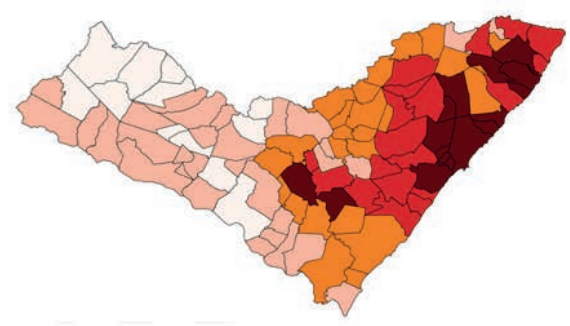

A) mean incidence rates 2007-2011; B) mean incidence rates 2012-2016); C) rates corrected

by the empirical Bayesian model 2007-2011; D) rates corrected by the empirical Bayesian model 2012-2016.

Figure 2. Mean incidence rates of HIV and rates corrected by the empirical Bayesian model in Alagoas, Brazil. 
period of 2012-2016, indicating the evidence of positive spatial autocorrelation between municipalities. Thus, neighbouring municipalities tend to be equal to each other in terms of the incidence rate of HIV. When decomposing this global spatial association index, predominant clusters were observed in the eastern region, which expanded in the second period. The information in the Moran map (Figure 2) identified clusters with a statistical significance classified according to their position in the scatter diagram. Nineteen municipalities had a higher risk (Q1 Moran map high/high) for virus transmission in the first period and 16 in the second period (Japaratinga, Porto Calvo, Porto de Pedras, Passo de Camaragibe, Novo Lino, Maceió, Paripueira, Barra de Santo Antônio, São Luiz do Quitunde, Satuba, Santa Luzia do Norte, Marechal Deodoro, Rio Largo, Messias, Pilar and Atalaia).

It is also possible to view areas in epidemiological transition (Piranhas, Pão de Açúcar, Porto Real do Colégio and Palmeira dos Índios), but not grouped, as they present municipalities with rates opposite to the surrounding ones, represented by high and low HIV/AIDS detection values in the Q3 Moran map (Figure 3). The statistical Moran's $I$ showed a positive and significant spatial correlation $(I=0.21, \mathrm{P}=0.000)$ for the incidence of HIV in municipalities. Once the existence of spatial autocorrelation was observed, the complete SAR model (Table 1) explained $46 \%$ of the incidence of HIV in the state of Alagoas during the period $\left(\mathrm{R}^{2}=\right.$ $0.46, \mathrm{P}=0.00$ ). The HIV incidence rate was estimated by the Gini index $(\mathrm{P}=0.00)$, proportion of heads of household without or with low education $(\mathrm{P}=0.02)$ and rate of primary health care units $(\mathrm{P}=$ $0.00)$. The Moran's $I$ for residues was 0.008 .

\section{Discussion}

Among developing countries, Brazil was a pioneer in guaranteeing access to free and universal antiretroviral treatment through the Unified Health System. This fact resulted in a substantial improvement in the prognosis of people living with HIV, a reflection of viral suppression in the blood. In addition, the rapid and continuous suppression of the virus also makes it possible to prevent new cases, as it has already been proven with a $99 \%$ drop in HIV transmissibility in these cases, even in the face of the practice of sexual relations in which the female condom or male condom would not be used (Rodger et al., 2016). When considering this advance, it would be expected to observe a decrease in new HIV infections in the country. This would result in a minimization of economic costs due to the reduction of disabilities and deaths related to opportunistic infections, hospitalizations and the performance of clinical and laboratory procedures of high complexity.

However, in the State of Alagoas, there was an increasing trend in the epidemic over the 10 years analysed in this study. This can be attributed not only to gaps in the implementation of prevention

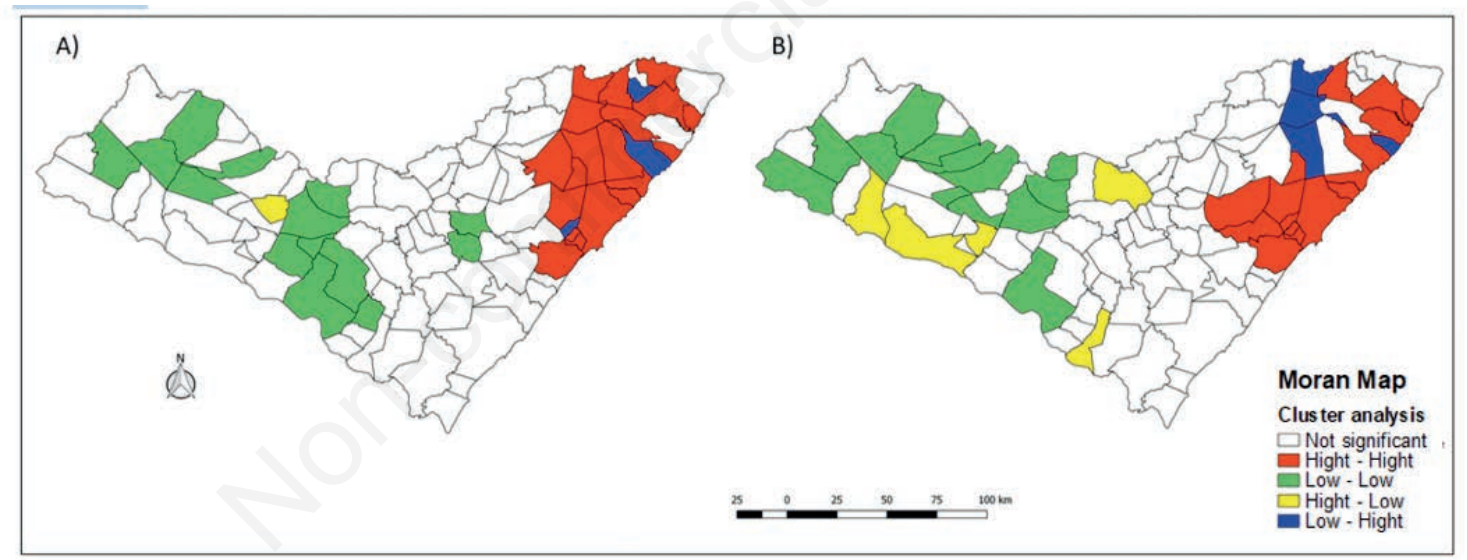

A) results for the period 2007-2011; B) results for the period 2012-2016.

Figure 3. Moran's map analysis using the average incidence rate of HIV in Alagoas, Brazil.

Table 1. Spatial regression model with HIV incidence rate and socioeconomics variables in Alagoas, Brazil, 2007-2016.

\begin{tabular}{lccc}
\hline Variable & Coefficient & Standard Error & P-value \\
Constant & 5.4806 & 1.6435 & 0.0009 \\
Average household income per capita & -0.0009 & 0.0007 & 0.1503 \\
\hline Gini index & -2.2874 & 0.6115 & 0.00018 \\
Illiteracy rate & 0.0080 & 0.0102 & 0.4347 \\
\hline Proportion of heads of household without or with low education & -0.0275 & 0.0119 & 0.0204 \\
Unemployment rate & 0.0112 & 0.0080 & 0.1587 \\
\hline MHDI & -2.8789 & 1.7647 & 0.1028 \\
Rate of primary health care units & 0.0212 & 0.0066 & 0.0014 \\
\hline
\end{tabular}


strategies and prophylaxis in sexual risk exposure (CrabtreeRamírez et al., 2020), but also to the improvement in the quality of the notifications of the disease and to the increase in the coverage of the offer of rapid tests for diagnosis of the infection encouraged in primary care services since $2013(\mathrm{MoH}, 2013$; 2014). Before that, rapid HIV tests in Brazil were traditionally carried out in specialized clinics (Melo et al., 2018; Pinho et al., 2020; Rocha et al., 2016). In this context, the results of our spatial regression showed that the HIV incidence rate can be explained positively by the variable rate of basic health units in the municipalities. Even so, it is important to note that the increase in the number of new HIV infections has also been seen in all other countries in Latin America (Crabtree-Ramírez et al., 2020).

The analyses of the present study also identified critical areas of risk in relation to the HIV incidence rate. This characterizes infection as a multifaceted and spatially dependent phenomenon among municipalities. The existence of clusters that leave coastal regions and migrate to the areas of the interior was found. The correction of the HIV incidence rate by the local Bayesian method allowed us to minimize possible distortions of the variability provided by the calculation of the crude rates due to the size of the population at risk. This rate adjustment was more consistent from an epidemiological point of view, since it showed a more uniform pattern of risk that also expands into the interior region. It has presented municipalities with worrying values, because they extrapolate the global index and the current national situation.

The results presented by the Moran map point to the risk that also exists in areas considered to be in epidemiological transition, albeit in isolation in certain parts of the interior and hinterlands. This is considered important, since the dynamics of virus transmission are not limited to political boundaries and can be influenced by the intensity of the flow of people, population density, migration, tourism, market, work and cultural diversity (Holanda et al., 2015). It is important to highlight that many of these areas that presented high risk or transition clusters in the mappings are considered host communities, whose socioeconomic organization is predominantly focused on tourism, such as the municipalities of Japaratinga, Porto de Pedras, Maceió, Marechal Deodoro and Piranhas, and having natural attractions, mainly composed of beaches and canyons. Some authors have highlighted an intensification of sociosexual interactions in coastal regions due to the seasonal flow of people with varied cultural profiles and behaviours, which can contribute to greater vulnerability for sexually transmitted infections in Brazilian and international communities (Figueiredo et al., 2007; Santos et al., 2007; Bellenzani et al., 2008; Padilla et al., 2010; Simkhada et al., 2016).

The most homogeneous areas of the western regions of Alagoas, considered low risk by Moran's analyses, show a need to reinforce the investigation of managers in relation to the population's access to rapid test technology in small municipalities, since it may mean the presence of inequality of programmatic and structural strategies in relation to large urban centres. Despite the existence of an interiorization process observed over time in the analyses of this study, the predominance of diagnoses reported in individuals living in the state capital or in geographically close locations seems to reflect this disparity in the distribution of health professionals and accessibility to services between geographic locations, as has been observed in other studies (Silveira et al., 2014; Garnelo et al., 2018).

The persistence of regional inequalities in living conditions is also reflected in the results of a positive and statistically significant relationship between the HIV incidence rate and the indicator of low education of those responsible for the households and the negative relationship income inequality of the Gini index. These results may indicate that people with greater social vulnerability may still be facing greater difficulties in accessing diagnosis. A similar result has also been found in other studies (Bingenheimer, 2010; Paiva et al., 2019), although an impoverishment process has been observed since the beginning of the epidemic (Parker et al., 2000; Bastos et al., 2000; Pascoe et al., 2015; Steinert et al., 2017). Within the scope of these findings, the proximity of the health service to the community from the decentralization of monitoring people living with HIV to services closer to their home could contribute to lower levels of bureaucracy and equity in patient accessibility at local levels, provide ease of drug withdrawal and facilitate the use of cost-effective approaches for better access to care, especially for key populations in areas that are difficult to reach (Hofer et al., 2019). However, reducing the distance to assistance should only be considered as an initial step, because the transition from this decentralized policy has barriers that have already been described. Potential weaknesses in basic community care can compromise this process, especially with regard to the reticence of health providers who do not commonly deal with HIV/AIDS in discussing sexual identity and issues related to homoaffective relationships in their routine care, a fact that it gets even worse due to the higher turnover of professionals and incomplete teams in primary care (Zambenedetti et al., 2016). This shows the importance of joint management actions in order to qualify the most diverse levels of complexity of the health units for the care and subsequent monitoring of HIV cases.

In view of the variables presented, this research provides evidence of how the social determination and spatial dependence of the municipalities can be related to the increased incidence of HIV. It is reiterated that the infection epidemic is marked by inequalities. Although living conditions are not the direct causes of virus transmission, each socioeconomic condition of the studied geographical spaces contributes to the inequities that increase or decrease the risk of its acquisition by understanding that social contexts shape spatial relationships. Therefore, prevention and control strategies can be established according to each reality.

Some limitations of this study must be noted. The data used are based on information systems records, and therefore, there is a chance of underreporting of cases and imprecision of quality. Despite this, the research method was conducted on a large data set and showed evident significant results. Such information can serve as a basis for comparison with other studies and for planning strategies linked to health policies.

\section{Conclusions}

This study analysed multiple socioeconomic indicators in the occurrence of HIV infection. Despite the heterogeneity in rates, there was a growing trend in cases between 2007 and 2016 in general in the region studied, being more expressive among municipalities in the interior of the state. The relationship found between indicators of better social conditions and HIV infection suggests unequal access to the diagnosis of infection.

The analysis instrumented by geoprocessing indicated the formation and establishment of areas of continuous transmission, transition and social vulnerability in the State over the period, demonstrating a useful technique for monitoring HIV and for the 
efficient use of public health resources by defining strategies directed at priority locations with a view to preventing infection, early diagnosis and promoting effective adherence to treatment.

\section{References}

Almeida E, 2012. Econometria espacial aplicada. Campinas, SP: Alínea, 498 pp. Available from: https:/www.grupoatomoealinea.com.br/econometria-espacial-aplicada.html

Anselin L, 2005. Exploring a spatial data with GeoDaTM: a workbook. Rev. version. Urbana Center for Spatially Integrated Social Science of University of Illinois, USA. Available from: https://www.geos.ed.ac.uk/ gisteac/fspat/geodaworkbook.pdf

Barankanira E, Molinari N, Niyongabo T, Laurent C, 2016. Spatial analysis of HIV infection and associated individual characteristics in Burundi: indications for effective prevention. BMC Public Health 16:1-11.

Bastos F, Szwarcwald C, 2000. AIDS and pauperization: principal concepts and empirical evidence. Cad Saúde Pública 16:65-76. doi:10.1590/S0102-311X2000000700006

Bellenzani R, Blessa C, Paiva V, 2008. [Scripts em cena: HIV e mercado sexual no contexto turístico.] Psicol Estud 13:653662. [Article in Portuguese].

Bingenheimer J, 2010. Men's multiple sexual partnerships in 15 Sub-Saharan African countries: sociodemographic patterns and implications. Stud Fam Plann 41:1-17. doi:10.1111/j.17284465.2010.00220.x.

Bose S, 2017. Demographic and spatial disparity in HIV prevalence among incarcerated population in the US: a state-level analysis. Int J STD AIDS 29:278-86. doi:10.1177/0 956462417724586

Crabtree $\square$ Ramírez B, Belaunzarán $\square$ Zamudio PF, Cortes CP, Morales M, Sued O, et al., 2020. The HIV epidemic in Latin America: a time to reflect on the history of success and the challenges ahead. J Int AIDS Soc 23:e25468. doi: 10.1002/ jia2.25468

Figueiredo R, Mcbritton M, 2007. [Cultura de turismo e população litorânea: contatos afetivo-sexuais de verão.] Bol Inst Saúde 41. Available from: https://www.researchgate.net/ publication/228522203_Cultura_de_Turismo_e_Populacao_Litorane a_contatos_afetivo-sexuais_de_Verao

Galvão J, 2002a. Access to antiretroviral drugs in Brazil. The Lancet 360:1862-5. doi:10.1016/S0140-6736(02)11775-2.

Galvão J, 2002b. Brazilian policy for the distribution and production of antiretroviral drugs: a privilege or a right? Cad Saúde Pública 18: 213-9. Available from: https://www.scielo.br/scielo.php?pid=S0102-311X2002000100022\&script=sci_abstract

Garnelo L, Lima J, Rocha E, Herkrath F, 2018. [Acesso e cobertura da atenção primária à saúde para populações rurais e urbanas na região norte do Brasil.] Saúde debate 42, n. 1, set. 2018. doi:10.1590/0103-11042018S106. [Article in Portuguese].

Grangeiro A, Castanheira ER, Nemes MIB, 2015. The reemergence of the Aids epidemic in Brazil: Challenges and perspectives to tackle the disease. Interface - Comunicação, Saúde, Educação 19:5-8. doi:10.1590/1807-57622015.0038

Holanda E, Galvão M, Pedrosa N, Paiva S, Almeida R, 2015. [Análise espacial da infecção pelo vírus da imunodeficiência humana entre gestantes.] Rev Latino-Am Enfermagem 23:4419. doi:10.1590/0104-1169.0481.2574 [Article in Portuguese].

Hofer C, Magalhães M, Frota A, Oliveira R, Abreu T, et al., 2019.
HIV Vertical transmission in Rio de Janeiro, Brazil: does the distance matter? AIDS Care 31:314-7. doi:10.1080/09540121. 2018. 1515466.

IBGE, 2010. [Censo Demográfico 2010]. Available from: https://sidra.ibge.gov.br/pesquisa/censo-demografico/ demografico-2010/inicial [Website in Portuguese].

IBGE, 2019. [Cidades e Estados: Características da População 2019.] Available from: https://www.ibge.gov.br/cidades-eestados/al.html [Website in Portuguese].

IPEA, 2015. [Atlas da vulnerabilidade social nos municípios brasileiros.] Available from: http://ivs.ipea.gov.br/images/publicacoes/Ivs/publicacao_atlas_ivs.pdf [Website in Portuguese].

Melo EA, Maksud I, Agostini R, 2018. HIV/Aids management at the primary care level in Brazil: a challenge for the Unified Health System? Rev Panam Salud Publica 42:e151. doi:10.26633/RPSP.2018.151

Momenyan S, Kavousi A, Poorolajal J, Momenyan N, 2018. Spatial inequalities and predictors of HIV/AIDS mortality risk in Hamadan, Iran: a retrospective cohort study. Epidemiol Health 40:e2018038. doi:10.4178/epih.e2018038

Ministry of Health, Brazil (MoH), 2013. [Portaria n 3.275 , de 26 de dezembro de 2013. Dispõe sobre a realização de testes rápidos, na atenção básica, para a detecção de HIV e sífilis. Ministério da Saúde.] Available from: http://bvsms. saude.gov.br/bvs/saudelegis/gm/2013/prt3275_26_12_2013.ht $\mathrm{ml}$. [Website in Portuguese].

Ministry of Health, Brazil (MoH), 2014. [Portaria n ${ }^{\circ} 1.271$, de 6 de junho de 2014. Define a Lista Nacional de Notificação Compulsória de doenças, agravos e eventos de saúde pública nos serviços de saúde públicos e privados em todo o território nacional. Ministério da Saúde.] Available from: http://bvsms. saude.gov.br/bvs/saudelegis/gm/2014/prt1271_06_06_2014.ht ml. [Website in Portuguese].

Ministry of Health, Brazil (MoH), 2018. [Secretaria de vigilância em saúde, departamento de vigilância, prevenção e controle das IST, HIV/Aids e hepatites virais. Boletim Epidemiológico HIV/Aids. Ministério da Saúde.] Available from: http://www. aids.gov.br/pt-br/pub/2018/boletim-epidemiologico-hivaids2018. [Website in Portuguese].

Paiva S, Pedrosa N, Galvão M, 2019. [Análise espacial da Aids e os determinantes sociais de saúde.] Rev Bras Epidemiol 22. [Article in Portuguese]. doi:10.1590/1980-549720190032

Parker R, de Camargo Jr K, 2000. [Poverty and HIV/AIDS: anthropological and sociological aspects.] Cad Saúde Pública 16:89-102. [Article in Portuguese]. doi:10.1590/S0102-311X2 000000700008

Pascoe S, Langhaug L, Mavhu W, Hargreaves J, Jaffar S, et al., 2015. Poverty, food insufficiency and HIV infection and sexual behaviour among young rural Zimbabwean women. PLoS One 10: e0115290. doi:10.1371/journal.pone.0115290

Padilla MB, Guilamo-Ramos V, Bouris A, Reyes AM, 2010. HIV/AIDS and tourism in the Caribbean: an ecological systems perspective. Am J Public Health 100,1:70-7. doi:10.2105/AJPH.2009.161968.

Pinho CM, Dourado C, Lima MCL, Maia TS, Silva JFAS, et al., 2020. [Avaliação das medidas de controle do HIV na atenção básica.] Rev Eletr Acervo Saude 12:2-14. [Article in Portuguese]. doi:10.25248/reas.e3462.2020

Qian S, Guo W, Xing J, Qin Q, Ding Z, et al., 2014. Diversity of HIV/AIDS epidemic in China: a result from hierarchical clustering analysis and spatial autocorrelation analysis. AIDS 
28:1805-13. doi:10.1097/qad.0000000000000323

Rocha KB, Santos RRG, Conz J, Silveira ACT, 2016. [Network transversality: matrix support in the decentralization of counseling and rapid testing for HIV, syphilis, and hepatitis.] Saúde Debate 40:22-33. [Article in Portuguese]. doi:10.1590/01031104201610902

Rodger A, Cambiano V, Bruun T, Vernazza P, Collins S, et al., 2016. Sexual activity without condoms and risk of HIV transmission in serodifferent couples when the HIV-positive partner is using suppressive antiretroviral therapy. JAMA 31:171-81. doi:10.1001/jama.2016.5148.

Santos A, Paiva V, 2007. [Vulnerabilidade ao HIV: turismo e uso de álcool e outras drogas.] Rev Saúde Pública 41: 80-86. [Article in Portuguese]. doi:10.1590/S0034-891020070009 00013

Silveira R, Pinheiro R, 2014. [Entendendo a necessidade de médicos no interior da Amazônia - Brasil.] Rev Bras Educ Med 38:451-9. [Article in Portuguese]. doi:10.1590/S010055022014000400006.

Simkhada P, Sharma A, Van Teijlingen E, Beanland R, 2016. Factors influencing sexual behaviour between tourists and tourism employees: a systematic review. Nepal J Epidemiol 6:530-8. doi:10.3126/nje.v6i1.14735

de Sousa AI, Pinto Júnior VL, 2016. Spatial and temporal analysis of Aids cases in Brazil, 1996-2011: increased risk areas over time. Epidemiol Serv Saude 25:467-76. doi:10.5123/S167949742016000300003

Steinert J, Cluver L, Melendez-Torres G, Herrero R, 2017. Relationships between poverty and AIDS illness in South Africa: an investigation of urban and rural households in KwaZulu-Natal. Glob Public Health 12:1183-99. doi:10.
1080/17441692.2016.1187191

UNAIDS, 2019. 90-90-90: an ambitious treatment target to help end the AIDS epidemic. Available from: https://www.unaids. org/sites/default/files/media_asset/90-90-90_en.pdf

Xing J, Li Y, Tang W, Guo W, Ding Z, et al., 2014. HIV/AIDS Epidemic among older adults in China during 2005-2012: results from trend and spatial analysis. Clin Infect Dis 59:e53e60. doi:10.1093/cid/ciu214

Wabiri N, Shisana O, Zuma K, Freeman J, 2016. Assessing the spatial nonstationarity in relationship between local patterns of HIV infections and the covariates in South Africa: a geographically weighted regression analysis. Spat Spatiotemporal Epidemiol 16:88-99. doi:10.1016/j.sste.2015.12.003

Wand H, Ramjee G, 2015. Spatial clustering of "measured" and "unmeasured" risk factors for HIV infections in hyper-endemic communities in KwaZulu-Natal, South Africa: results from geoadditive models. AIDS Care 27:1375-81. doi:10.1080/ 09540121.2015 .1096896

Zambenedetti G, Silva R, 2016. [Descentralização da atenção em HIV/Aids para a atenção básica: tensões e potencialidades.] Physis 26:785-806. [Article in Portuguese]. doi:10.1590/ s0103-73312016000300005

Zhang Y, Xiao Q, Zhou L, Ma D, Liu L, Lu R, Yi D, Yi D, 2015. The AIDS epidemic and economic input impact factors in Chongqing, China, from 2006 to 2012: a spatial-temporal analysis. BMJ Open 5:e006669. doi:10.1136/bmjopen-2014006669

Zulu L, Kalipeni E, Johannes E, 2014. Analyzing spatial clustering and the spatiotemporal nature and trends of HIV/AIDS prevalence using GIS: the case of Malawi, 1994-2010. BMC Infect Dis 14:285. doi:10.1186/1471-2334-14-285. 